\title{
The Urease of Ureaplasma urealyticum
}

\author{
By D. THIRKELL, ${ }^{*}$ ALISON D. MYLES, B. L. PRECIOUS, J. S. FROST, \\ JULIE C. WOODALL, M. G. BURDON AND W. C. RUSSELL \\ Department of Biochemistry and Microbiology, University of St Andrews, Irvine Building, \\ North Street, St Andrews, Fife KYI6 9AL, UK
}

(Received 1 June 1988; revised 3 October 1988; accepted 25 October 1988)

The urease from Ureaplasma urealyticum (serotype 8) has been purified by immuno-affinity column chromatography. Two active nickel-containing forms of the enzyme were demonstrated by non-denaturing electrophoretic analysis and a single active peak of apparent molecular mass $190 \mathrm{kDa}$ was shown by FPLC. Total inactivation and denaturation of the enzyme to give three subunit polypeptides (one of $72 \mathrm{kDa}$ containing nickel, one of $14 \mathrm{kDa}$ and one of $11 \mathrm{kDa}$ ) was achieved by treatment with SDS and boiling. Densitometry suggested that the active enzyme contains equimolar ratios of the three subunits and hence is a hexamer. The enzyme displayed a $\mathrm{pH}$ optimum of 6.9 and $\mathrm{pI}$ values were determined. Storage of the purified enzyme at $-70^{\circ} \mathrm{C}$ followed by thawing to $20^{\circ} \mathrm{C}$ caused a partial breakdown to inactive subunits. Anti-urease monoclonal antibodies bound both to the active enzyme and to the inactive $72 \mathrm{kDa}$ subunit, and the antibodies cross-reacted with ureases from all of the other human serotypes. Competition assays with the antibodies revealed four distinct epitopes on the enzyme, all distinct from its active site.

\section{INTRODUCTION}

Mycoplasmas are members of the Mollicutes, the smallest and simplest of the self-replicating prokaryotes, and they do not possess a cell wall. Among the Mollicutes, the ureaplasmas are unique in their ability to hydrolyse urea and indeed, they require urea to support growth (Kenny \& Cartwright, 1977). The urease of the ureaplasmas is cytosolic (Masover et al., 1977a), and Romano et al. (1986) have reported that ATP production by the cells requires the concomitant activity of the cytosolic urease and a membrane-bound ATPase. It has also been reported (Pollack, 1986) that the ureaplasmas lack the normal energy-producing metabolic pathways. Little is known about this important enzyme, the most recent information having been presented by Stemke et al. (1987). In this study, we have investigated some of the characteristics of the ureaplasma urease after purification using an anti-urease monoclonal antibody affinity column.

\section{METHODS}

Ureaplasma urealyticum strains. Serotype 1 (T7), serotype 4 (11860), serotype 6 (12253) and serotype 8 (T970) were gifts from Dr D. Taylor-Robinson (CRC, Harrow, UK). Serotype 7 (ATCC 27819) was obtained from the American Type Culture Collection. All other serotypes (2-T23; 3-DKF3; 5-NIH5; 9-9-Vancouver; 10-10 Western; 11-11 JsL2, 12-JsL5; 13-13 JsL6 and 14-14 JsL11) were gifts from Professor J. Robertson (University of Alberta, Edmonton, Canada).

Medium and cell production. Ureaplasmas were grown in medium containing 70\% (v/v) PPLO broth (Difco), $20 \%(\mathrm{v} / \mathrm{v})$ horse serum $(\mathrm{NBL})$ and $2.5 \%(\mathrm{w} / \mathrm{v})$ fresh yeast extract, incorporating $0.1 \%$ urea, $0.005 \%$ phenol red and $10^{3} \mathrm{IU}$ penicillin $\mathrm{G} \mathrm{ml} \mathrm{m}^{-1}$, usually at a starting $\mathrm{pH}$ of 6.0 . Cultures were incubated at $37^{\circ} \mathrm{C}$ until a $\mathrm{pH}$ of 7.6 , corresponding to a cell density of $10^{7}$ c.c.u. $\mathrm{ml}^{-1}$, was reached (c.c.u., colour-change units: see below), the cells were harvested by centrifugation using a Beckman $\mathrm{J}-21$ rotor $(25000 \mathrm{~g}, 20 \mathrm{~min})$, the pellets were washed once in Dulbecco's phosphate-buffered saline 'A' (PBS) (Dulbecco \& Vogt, 1954) and the final pellet was resuspended in PBS. 
In some experiments during batch cultures, portions were removed at predetermined time intervals and the $\mathrm{pH}$ of the medium was measured together with a titration of the c.c.u. $\mathrm{ml}^{-1}$ to give an indication of cell growth. To determine the c.c.u. $\mathrm{ml}^{-1}$, serial decimal dilutions of $0.2 \mathrm{ml}$ of culture in vials containing $1.8 \mathrm{ml}$ of growth medium were incubated at $37^{\circ} \mathrm{C}$ until no further colour change of the phenol red indicator was apparent (normally $48 \mathrm{~h}$ ). From the lowest dilution in which a colour change was seen the no. of c.c.u. per $\mathrm{ml}$ of original culture was determined.

For labelling with ${ }^{63} \mathrm{Ni},{ }^{63} \mathrm{NiCl}_{2}\left[1.02 \mu \mathrm{Ci}(37.7 \mathrm{kBq}) \mu \mathrm{l}^{-1} ; 0.093 \mu \mathrm{g} \mathrm{Ni} \mathrm{ml}{ }^{-1}\right]$ (Amersham) was used. Cultures $(200 \mathrm{ml})$ were grown as above but with the medium made $1 \mu \mathrm{Ci} \mathrm{ml^{-1 }}$ with respect to ${ }^{63} \mathrm{Ni}$.

Purification of urease from U. urealyticum serotype 8. Monoclonal antibody (UU8/1) (Precious et al., 1987) was partially purified by precipitation with $50 \%$ saturated ammonium sulphate and, after dialysis against PBS, passed through a column of Sephadex G200 (Fahey \& Terry, 1978). Samples of each fraction from the column, in PBS, were diluted with an equal volume of 'denaturing mix' ( $5 \mathrm{M}$-urea, $3 \cdot 5 \mathrm{M}-\beta$-mercaptoethanol, $2 \%$, $w / v$, SDS $)$, boiled for $2 \mathrm{~min}$ and electrophoresed on a $15 \%(\mathrm{w} / \mathrm{v})$ gel (SDS-PAGE). Fractions containing heavy and light chain immunoglobulin bands were identified by comparison with appropriate molecular mass markers. These fractions were pooled, and approximately $60 \%$ of the total proteins in the pooled fractions was ascribed to immunoglobulins. Immunoglobulin $(5 \mathrm{mg}$ ) was coupled to $1 \mathrm{~g}$ of cyanogen-bromide-activated Sepharose $4 \mathrm{~B}$ (Sigma) by standard techniques (Axen et al., 1967). The total cell pellet from a 5 or 10 litre culture was resuspended in 2 or $4 \mathrm{ml}$ PBS containing $0.2 \%(\mathrm{v} / \mathrm{v})$ Nonidet P40 (PBS-N), placed on ice and sonicated $(4 \times 10 \mathrm{~s}$ with cooling between bursts) using a $0.5 \mathrm{~cm}$ microprobe on a Kerry ultrasonicator. After centrifugation (Microfuge, 13000 r.p.m., $5 \mathrm{~min}$ ), the supernatant was removed and retained and the pellet was re-extracted three times. Pooled supernatants were centrifuged again (Microfuge, 13000 r.p.m., $20 \mathrm{~min}$ ), and the supernatant was applied to the affinity column. The column was washed through with PBS-N, and when the wash was free of protein (detected by dot-blotting on nitrocellulose paper and staining with naphthalene black), the urease was eluted with $0 \cdot 1 \mathrm{M}$-borate buffer, $\mathrm{pH} 10.0$ (detected as above), and collected in $0.5 \mathrm{ml}$ portions in tubes containing one drop of $1 \mathrm{M}-\mathrm{Tris} / \mathrm{HCl}$, $\mathrm{pH} 7 \cdot 6$. Pooled enzyme-containing fractions were dialysed overnight $\left(4^{\circ} \mathrm{C}\right)$ against $\mathrm{PBS}$ and used either directly or after storage at $-70^{\circ} \mathrm{C}$ in the presence or absence of $50 \%(\mathrm{v} / \mathrm{v})$ glycerol. Although no upper limit for the loading capacity of the immuno-affinity column was determined, it was in excess of the pooled supernatants obtained from a 10 litre culture at $10^{7}$ c.c.u. $\mathrm{ml}^{-1}$. An estimate of the activity of the purified enzyme was made using the Berthelot reaction as described previously (Precious et al., 1987), utilizing $\mathrm{NH}_{4} \mathrm{Cl}$ standards to calibrate the intensity of colour produced. The activity of the ureaplasma urease was calculated to be approximately $65000 \mathrm{units}^{-1} \mathrm{mg}^{-1}$ ( 1 unit of enzyme activity released $1 \mu \mathrm{mol}$ of $\mathrm{NH}_{3} \mathrm{~min}^{-1}$ at $25^{\circ} \mathrm{C}$ ). By comparison, a preparation of crystalline jack bean urease (Sigma), titrated in parallel, had an activity of 830 units $\mathrm{mg}^{-1}$. The urease activity recovered from the immuno-affinity column was about $60 \%$ of the total in the crude extract.

The ${ }^{63} \mathrm{Ni}$ radioactivity associated with the urease was eluted from the affinity column and was determined by scintillation counting.

Determination of the apparent molecular mass of urease by gel filtration (FPLC). An FPLC instrument (Pharmacia) was used with a $30 \mathrm{~cm}$ Superose 6 column. Elution was carried out with PBS at $0 \cdot 25 \mathrm{ml} \mathrm{min}^{-1}$ at $20^{\circ} \mathrm{C}$, and protein was detected at $280 \mathrm{~nm}$. The column was calibrated by applying a mixture of molecular mass standards within the range $12 \mathrm{kDa}$ to $640 \mathrm{kDa}$ (Sigma) under the same conditions. Fresh enzyme (200 $\mu \mathrm{l}$ in PBS) was applied to the column and $0.75 \mathrm{ml}$ fractions were collected. All fractions were assayed for urease activity by the Berthelot reaction (see Precious et al., 1987).

Antibody preparation. Polyclonal serum against serotype 8 was produced as described previously (Precious et al., 1987). For monoclonal antibodies, Balb/C mice were immunized with purified urease using an immunization schedule described previously (Precious et al., 1987). Screening for antibodies to the urease was carried out by radioimmunoassay using ${ }^{125}$ I-labelled protein A and by the 'urease enzyme catch test' (Precious et al., 1987) using purified urease as antigen.

Competition assays with anti-urease monoclonal antibodies. Two methods were used. In the first, the 'urease catch' test was used (Precious et al., 1987). Wells of a 96-well microtitre plate were coated with $100 \mu 1 / 200$ dilution (in PBS) goat anti-mouse immunoglobulins (Sigma). After overnight incubation $\left(4^{\circ} \mathrm{C}\right.$ ) and washing with PBS, all wells were coated with $100 \mu \mathrm{l}(1 / 100$ dilution in PBS) of a selected monoclonal antibody. After incubation ( $3 \mathrm{~h}$, $37^{\circ} \mathrm{C}$ ), washing with PBS, blocking with $3 \%(\mathrm{w} / \mathrm{v}) \mathrm{BSA}\left(30 \mathrm{~min}, 37^{\circ} \mathrm{C}\right)$ and a further wash with PBS, $100 \mu \mathrm{l}$ of preincubated diluted antibody/ureaplasma mixtures were added to separate rows $(100 \mu l$ exponential-phase ureaplasma cells diluted with an equal volume of PBS- $N$ containing test antibody at final dilutions from $1 / 50$ to $1 / 6400$ and incubated for $1 \mathrm{~h}$ at $\left.37^{\circ} \mathrm{C}\right)$. After incubation $\left(60 \mathrm{~min}, 37^{\circ} \mathrm{C}\right)$, washing once with PBS-N and three times with PBS, and addition of $100 \mu 15 \mathrm{~mm}$-deionized urea to each well, the plate was incubated for $40 \mathrm{~min}$ at $20^{\circ} \mathrm{C}$. To each well, $50 \mu \mathrm{l}$ phenol nitroprusside and $50 \mu \mathrm{l}$ alkaline hypochlorite were added (Sigma urea nitrogen colorimetric kit for the Berthelot reaction) and after $30 \mathrm{~min}$ at $20^{\circ} \mathrm{C}$, the absorbance was measured at $600 \mathrm{~nm}$ on a Multiskan plate reader (Flow Laboratories).

In the second, appropriate antibodies were purified on a protein A-Sepharose column (Goswami \& Russell, 
1983) and radiolabelled with ${ }^{125}$ I by the method of Hunter (1978). Unlabelled antibodies were then tested for their ability to compete with the radiolabelled antibodies by making four-fold dilutions of ascitic fluids (starting at a $1 / 20$ dilution) in an appropriate dilution of labelled antibody in PBS containing $1 \%(w / v)$ BSA. Cell extract produced by sonication of a fresh cell pellet resuspended in PBS-N was adsorbed onto a nitrocellulose sheet (60 min, $20^{\circ} \mathrm{C}$ ). The antibody mixtures were applied to the nitrocellulose sheet and incubated $\left(60 \mathrm{~min}, 20^{\circ} \mathrm{C}\right)$ as described by Randall et al. (1987).

pH-activity curve of urease. The activity of portions of freshly prepared enzyme was measured over a final $\mathrm{pH}$ range of 2.2-10.7. Throughout, a buffer mixture containing $6.7 \mathrm{~mm}$-citric acid, $6.7 \mathrm{~mm}$-phosphoric acid, $11 \mathrm{mM}-$ boric acid and $69 \mathrm{~mm}-\mathrm{NaOH}$ was used, the $\mathrm{pH}$ being adjusted with $0 \cdot 1 \mathrm{M}-\mathrm{HCl}$ (Geigy, 1970). To $45 \mu \mathrm{l}$ of each buffer, $50 \mu 115 \mathrm{~mm}$-deionized urea was added, the $\mathrm{pH}$ was checked and then $5 \mu \mathrm{l}$ urease (diluted 1/10 in PBS) was added before incubation $\left(40 \mathrm{~min}, 20^{\circ} \mathrm{C}\right)$. Phenol nitroprusside $(25 \mu \mathrm{l})$ and $25 \mu \mathrm{l}$ alkaline hypochlorite were added and after $30 \mathrm{~min}$ at $20^{\circ} \mathrm{C}$ the absorbance was measured at $600 \mathrm{~nm}$ on a Multiskan.

$S D S-P A G E$. The method of Russell \& Blair (1977) was followed, using either $10 \%(\mathrm{w} / \mathrm{v})$ or $15 \%(\mathrm{w} / \mathrm{v})$ polyacrylamide slab gels. Samples were prepared for electrophoresis, without prior heat treatment, in one of the following solutions (all at $20{ }^{\circ} \mathrm{C}$ and with $0.1 \%$, w/v, bromophenol blue): (a) $50 \%$ (v/v) glycerol; (b) $50 \%$ (v/v) glycerol $/ 1 \%(\mathrm{w} / \mathrm{v})$ SDS; $(c) 2.5 \mathrm{M}$-urea; $(d)$ a 'denaturing mix' with final concentrations of $2.5 \mathrm{M}$-urea, $1.75 \mathrm{M}-\beta$ mercaptoethanol, $1 \%(\mathrm{w} / \mathrm{v}) \mathrm{SDS}$. In addition, samples of urease stored at $-70^{\circ} \mathrm{C}$ and thawed to $20^{\circ} \mathrm{C}$ were prepared in each of solutions $(a)$ to $(d)$, then boiled for $2 \mathrm{~min}$ before SDS-PAGE. In all analyses, $0 \cdot 1 \%(\mathrm{w} / \mathrm{v})$ SDS was present in both buffers and gel. Protein on gels was detected by Coomassie stain or silver stain (Bio-Rad kit). Urease activity on gels was detected by the method of Fishbein (1969).

Apparent molecular masses were determined, where appropriate, by comparison with protein standards (Bethesda Research Laboratories).

For autoradiographs of ${ }^{63} \mathrm{Ni}$-labelled material, the gels were subjected to fluorography as described by Russell \& Blair (1977) and dried on a low-heat gel drier (Atto) before being exposed to X-ray film (Fuji RX).

Densitometry. Where appropriate, $15 \%(\mathrm{w} / \mathrm{v})$ gels of fully denatured enzyme $\left(2 \mathrm{~min}, 100^{\circ} \mathrm{C}\right)$ which had been stained with the Coomassie stain were subjected to densitometry using a Vitatron densitometer. The individual subunit peak areas were calculated and, on the basis of established molecular masses, the molar ratios of individual subunits established.

Immunoblotting. Electrophoretic transfer of proteins from polyacrylamide gels to nitrocellulose sheets was carried out on an Ancos semi-dry electroblotter according to the supplier's directions. The blots were blocked with $3 \%(w / v)$ BSA ( $30 \mathrm{~min}$, room temperature) and washed three times with PBS-N; the sheets were then cut into strips, which were incubated $\left(2 \mathrm{~h}, 37^{\circ} \mathrm{C}\right)$ with anti-urease monoclonal antibodies or with homologous polyclonal serum [normally $1 / 500$ in 50:50 (v/v) PBS-N : growth medium]. After washing three times with PBS-N, approximately $10^{6}$ c.p.m. of ${ }^{125} \mathrm{I}$-labelled protein $\mathrm{A}$ (Amersham) was added, then after incubation $\left(2 \mathrm{~h}, 20^{\circ} \mathrm{C}\right)$ and extensive washing with PBS-N, the strips were subjected to autoradiography using X-ray film (Fuji RX) and a Philips fast tungstate intensifying screen.

Isoelectric focusing. Portions $(10 \mu \mathrm{l})$ of native urease in PBS, urease denatured by boiling ( $2 \mathrm{~min})$, and a solution of standards (Bio-Rad), were subjected to isoelectric focusing on ampholine-PAG plates (pH 3.5-9.5) using a Multiphor II apparatus (LKB). The samples were electrophoresed for a total of 90 min under standard conditions with a constant voltage $(1000 \mathrm{~V})$ and an initial current of $25 \mathrm{~mA}$. The gels were then fixed $(1 \mathrm{~h})$ in $30 \%(\mathrm{v} / \mathrm{v})$ methanol, $10 \%(\mathrm{w} / \mathrm{v})$ trichloroacetic acid and $3.5 \%(\mathrm{w} / \mathrm{v})$ sulphosalicylic acid, washed $(2 \mathrm{~h})$ in several changes of $30 \%(\mathrm{v} / \mathrm{v})$ methanol, $12 \%(\mathrm{w} / \mathrm{v})$ trichloroacetic acid, then stained with the Coomassie stain or with silver stain (Bio-Rad kit). Simultaneously, portions of the same enzyme preparations were subjected to SDS-PAGE and the gels stained with Coomassie stain.

\section{RESULTS}

\section{Subunit structure of the active urease}

The use of the immuno-affinity column followed by dialysis against PBS provided an efficient means of preparing purified urease in an active state. On average, about $1 \mathrm{mg}$ enzyme was recovered from the cell pellet obtained from a 10 litre ureaplasma culture. SDS-PAGE of freshly purified enzyme on a $10 \%$ gel without complete denaturation revealed only two closely migrating protein bands after staining with either Coomassie stain or the more sensitive silver stain. Two similar bands were shown to be enzymically active with the Fishbein stain (Fig. 1, lanes A and B) although the slower-migrating band was the more intense both by protein staining and in activity. Since the enzyme was not denatured prior to electrophoresis, molecular mass may not have been accurately reflected, but both bands were apparently within the 170 $200 \mathrm{kDa}$ range. To assess the molecular mass of the enzyme in another way, gel filtration was 


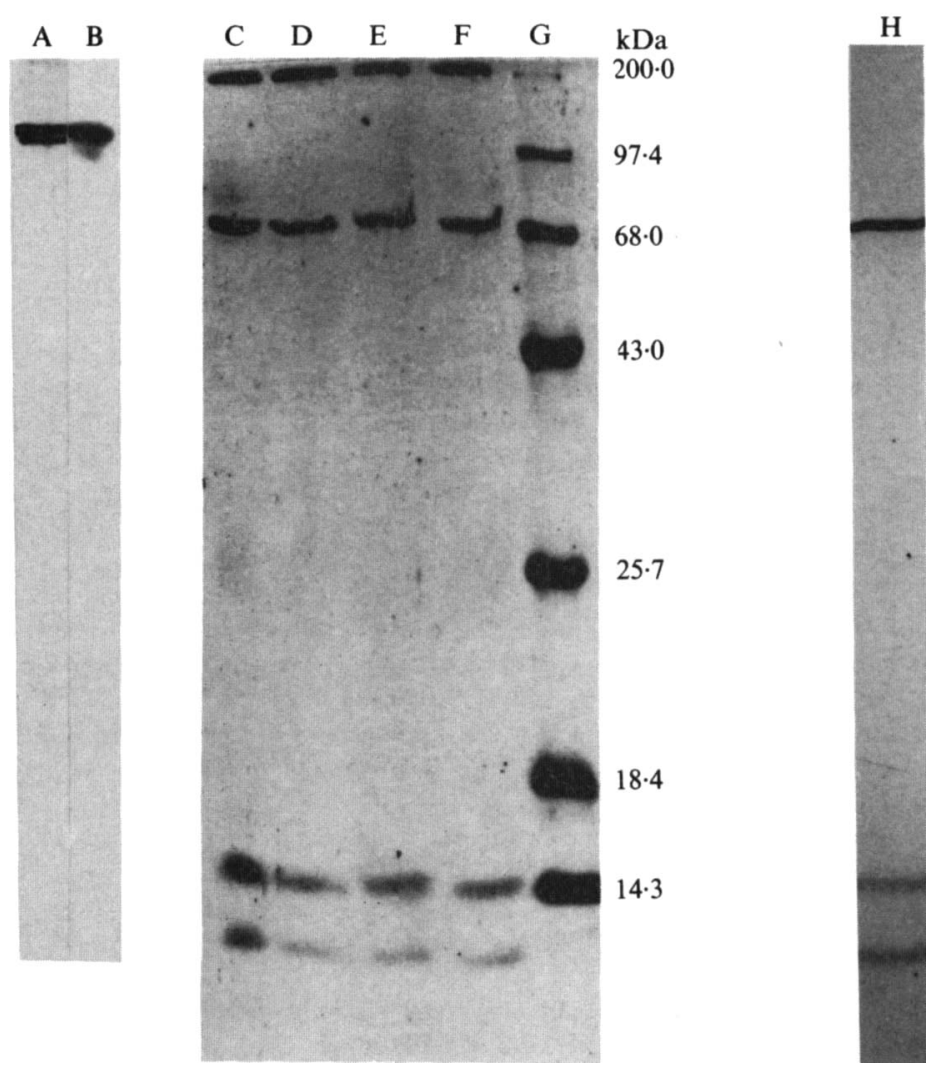

Fig. 1. SDS-PAGE analysis of polypeptides associated with purified urease. Lane A, $10 \%$ gel; freshly prepared urease (no prior heat treatment), silver stain. Lane B, $10 \%$ gel; freshly prepared urease (no prior heat treatment), Fishbein stain for urease activity. Lanes C-F, $15 \%$ gel; frozen urease thawed to room temperature $\left(20^{\circ} \mathrm{C}\right)$, distributed as indicated $(\mathrm{C}$, in $50 \%, \mathrm{v} / \mathrm{v}$, glycerol; $\mathrm{D}$, in $2.5 \mathrm{M}$ urea, $\mathrm{E}$, in $1.75 \mathrm{M}-\beta$-mercaptoethanol, $\mathrm{F}$, in 'denaturing mix'), and applied to the gel after incubation at $20^{\circ} \mathrm{C}$ for 10 min. Coomassie stain. Lane G, $15 \%$ gel; molecular mass standards. Lane $\mathrm{H}, 15 \%$ gel; urease after boiling ( $2 \mathrm{~min}$ ), Coomassie stain. All tracks were loaded with approximately $15 \mu \mathrm{g}$ urease, equivalent to 1000 units.

carried out on freshly prepared urease. A single major protein peak was eluted which was shown by the Berthelot reaction to be the active urease and which on a non-denaturing $10 \%$ SDSPAGE gel gave only the two active protein bands. By comparison of the elution volume of this peak with the elution volumes of the molecular mass standards, the apparent molecular mass of the urease was $190 \pm 10 \mathrm{kDa}$.

Boiling of the freshly prepared urease for 2 min resulted in loss of all enzyme activity and complete disaggregation to three subunit polypeptides with apparent molecular masses of $72 \pm$ $4 \mathrm{kDa}, 14 \pm 2 \mathrm{kDa}$ and $11 \pm 1 \mathrm{kDa}$ (Fig. 1, lane H). After SDS-PAGE of boiled urease, the gels stained with Coomassie stain were subjected to densitometry. Individual peak areas were calculated and, taking the apparent molecular masses of the subunits into consideration, it was shown that they were present in approximately equimolar ratios $(72 \mathrm{kDa}: 14 \mathrm{kDa}: 11 \mathrm{kDa}$ $1: 0.99: 0.95)$, consistent with the native enzyme being a hexamer $\left[(72 \mathrm{kDa})_{2}:(14\right.$ $\left.\mathrm{kDa})_{2}:(11 \mathrm{kDa})_{2}\right]$. Similar patterns were obtained with all batches of the purified enzyme.

\section{The urease contains nickel}

When the urease from a culture grown in the presence of ${ }^{63} \mathrm{NiCl}_{2}$ was purified by affinity chromatography, the radioactive label eluted as a peak with the enzyme (data not shown). Of the 

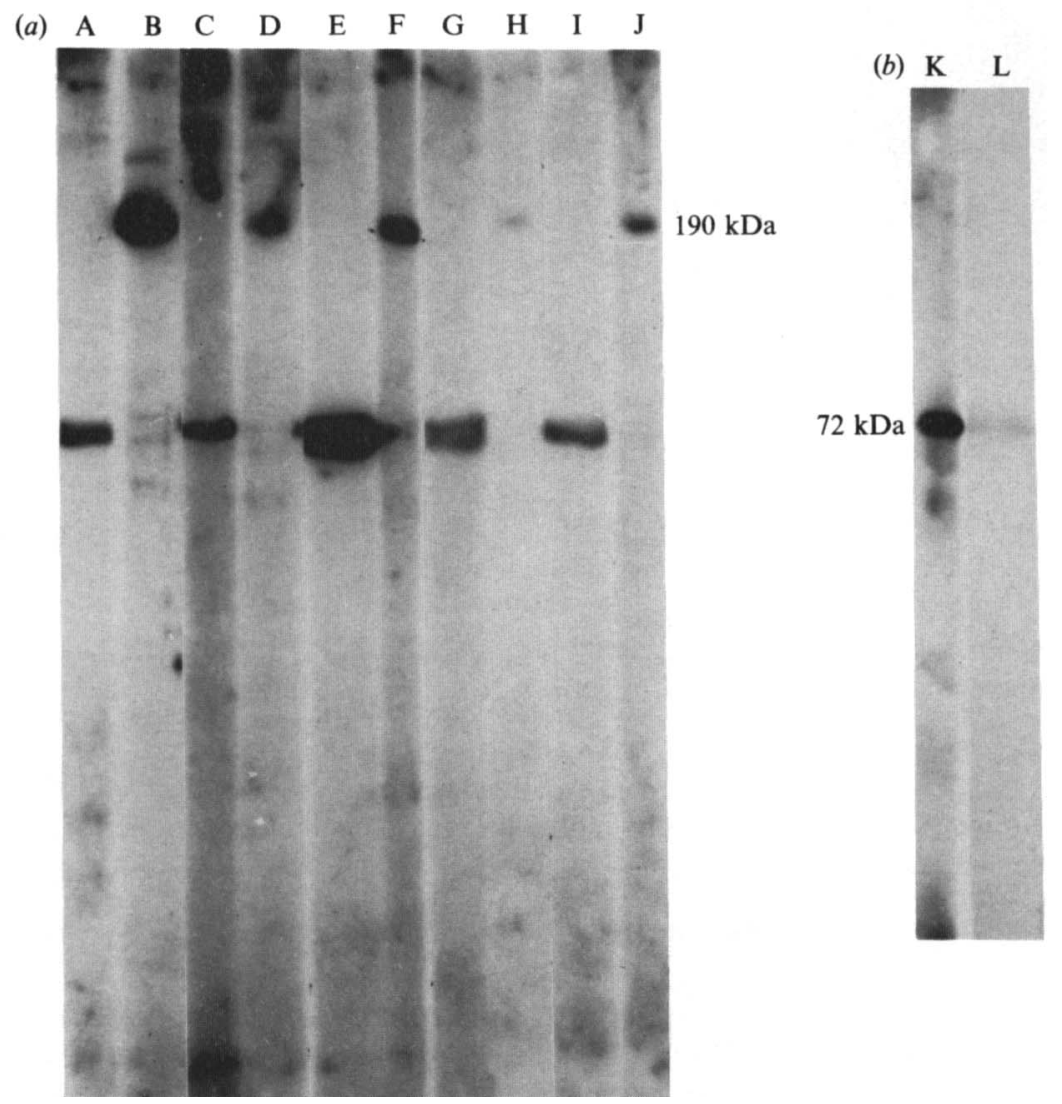

Fig. 2. (a) Analysis of urease antigen using the immunoblotting technique with ${ }^{125}$ I-labelled protein $A$. Lanes B, D, F, H and J contained freshly prepared urease; lanes A, C, E, G and I contained boiled enzyme. Lanes were probed with homologous polyclonal serum or with monoclonal antibodies of different epitope specificities (each raised against serotype 8), as follows: lanes A and B, polyclonal serum; lanes $C$ and $D, U U 8 / 11$; lanes $E$ and $F$, UU8/12; lanes $G$ and $H, U U 8 / 24$; lanes I and $J$, UU8/19. All tracks were loaded with approximately $15 \mu \mathrm{g}$ urease, equivalent to 1000 units.

(b) Electrophoretogram of boiled ${ }^{63} \mathrm{Ni}$-labelled urease. Lane $\mathrm{K}$, immunoblot of boiled ${ }^{63} \mathrm{Ni}$-labelled urease probed with anti-urease monoclonal antibody (UU8/19) and ${ }^{125}$ I-labelled protein A. Lane L, fluorogram of ${ }^{63} \mathrm{Ni}$-labelled boiled urease after exposure for 7 weeks.

total counts added, $45 \%$ was recovered in the purified urease preparation. Freshly labelled enzyme subjected to SDS-PAGE on a $10 \%$ gel without prior heat treatment again revealed two protein bands with molecular masses in the 170-200 kDa range. After exposure of a fluorograph for 7 weeks, the incorporation of ${ }^{63} \mathrm{Ni}$ into these two bands was demonstrated (data not shown).

After boiling, the ${ }^{63} \mathrm{Ni}$-labelled enzyme was subjected to SDS-PAGE on a $15 \%$ gel. One lane of the gel was immunoblotted with an anti-urease monoclonal antibody and the $72 \mathrm{kDa}$ subunit was detected (Fig. $2 b$, lane $\mathrm{K}$ ). The remainder of the gel was silver stained and a fluorograph exposed for 7 weeks. Labelling was detected in the $72 \mathrm{kDa}$ subunit, its position being confirmed by comparison with the silver stain and the immunoblot (Fig. $2 b$, lane $\mathrm{L}$ ).

\section{Stability of the enzyme}

Storage of the purified urease at $-70^{\circ} \mathrm{C}$ with or without added glycerol, in siliconized or nonsiliconized tubes, followed by thawing to $20^{\circ} \mathrm{C}$, resulted in a partial breakdown into the three subunits, and a $50-55 \%$ loss of activity. The active protein bands and the subunits were visualized, after non-denaturing SDS-PAGE, with Coomassie stain (Fig. 1, lanes C-F), and no 

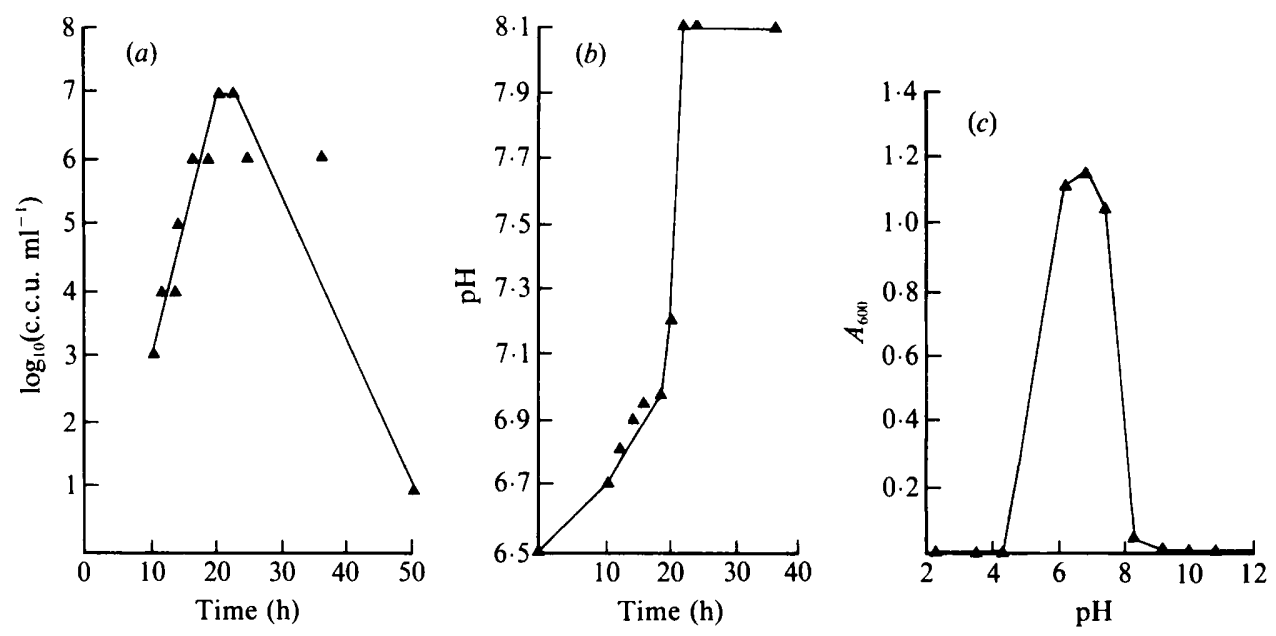

Fig. 3. (a) Growth (as c.c.u. production) of $U$. urealyticum serotype 8 during batch culture. (b) pH of culture medium during batch culture. (c) $\mathrm{pH}$-activity curve for purified urease (see Methods for details).

additional components could be detected by silver staining. At $20^{\circ} \mathrm{C}$, the addition of urea, $\beta$ mercaptoethanol or of 'denaturing mix' in the absence of boiling did not detectably accelerate enzyme breakdown over a period of $20 \mathrm{~min}$.

\section{pH optimum for enzyme activity}

The activity of fresh urease was determined in buffer preparations of various $\mathrm{pH}$ values as described in Methods. No enzyme activity was detected below $\mathrm{pH} 4 \cdot 3$ or above $\mathrm{pH} \mathrm{8.5}$, optimum $\mathrm{pH}$ for activity being found at pH 6.9 (Fig. $3 \mathrm{c}$ ). Whilst we would not expect the cytosolic urease to be sensitive to external $\mathrm{pH}$, it was noticeable that during batch culture, the external $\mathrm{pH}$ rose to and stabilized at $8 \cdot 1$ (Fig. $3 b$ ), which is close to the upper limit for enzyme activity. It is also noteworthy that as this pH plateau was reached, the culture entered a steep decline phase (Fig. $3 a)$.

\section{pI values of the enzyme}

After isoelectric focusing of an enzyme preparation which had been stored at $4{ }^{\circ} \mathrm{C}$ for $48 \mathrm{~h}$, three distinct and other faint bands were seen on silver staining (data not shown). The three distinct bands had pI values of 4.60, 4.68 and (the weakest band) 4.73. Non-denaturing electrophoretic analysis of this preparation showed that in addition to the two active protein bands, the $72 \mathrm{kDa}$ subunit was also seen with Coomassie stain. On isoelectric focusing of the enzyme preparation which had been boiled in the absence of denaturing agents, again three distinct bands were seen on silver staining, although two of these had different $p I$ values from those noted above: the most intense band had a pI value of 4.68 , and the two much less intense bands had pI values of 4.81 and 4.87. This preparation was also shown on electrophoretic analysis to contain the three subunits. These results indicated that the active enzyme had a $\mathrm{pI}$ of 4.60 , the $72 \mathrm{kDa}$ sub-unit a pI of 4.68 and the two smaller subunits had pI values of 4.81 and 4.87 . The minor enzymically active component presumably accounted for the band at pI $4 \cdot 73$.

\section{The urease has at least four distinct epitopes}

It has been shown previously (Precious et al., 1987) that an anti-urease monoclonal antibody (UU8/1) bound to both active protein bands of purified enzyme on an immunoblot. Eighteen additional anti-urease monoclonal antibodies (designated UU8/11-UU8/28) were raised, and all bound to active enzyme on immunoblotting as did an homologous polyclonal serum. Fig. $2(a)$ (lanes B, D, F, H, J) shows an immunoblot against polyclonal serum and against four monoclonal antibodies which each recognize a distinct epitope on the enzyme (see below). All 


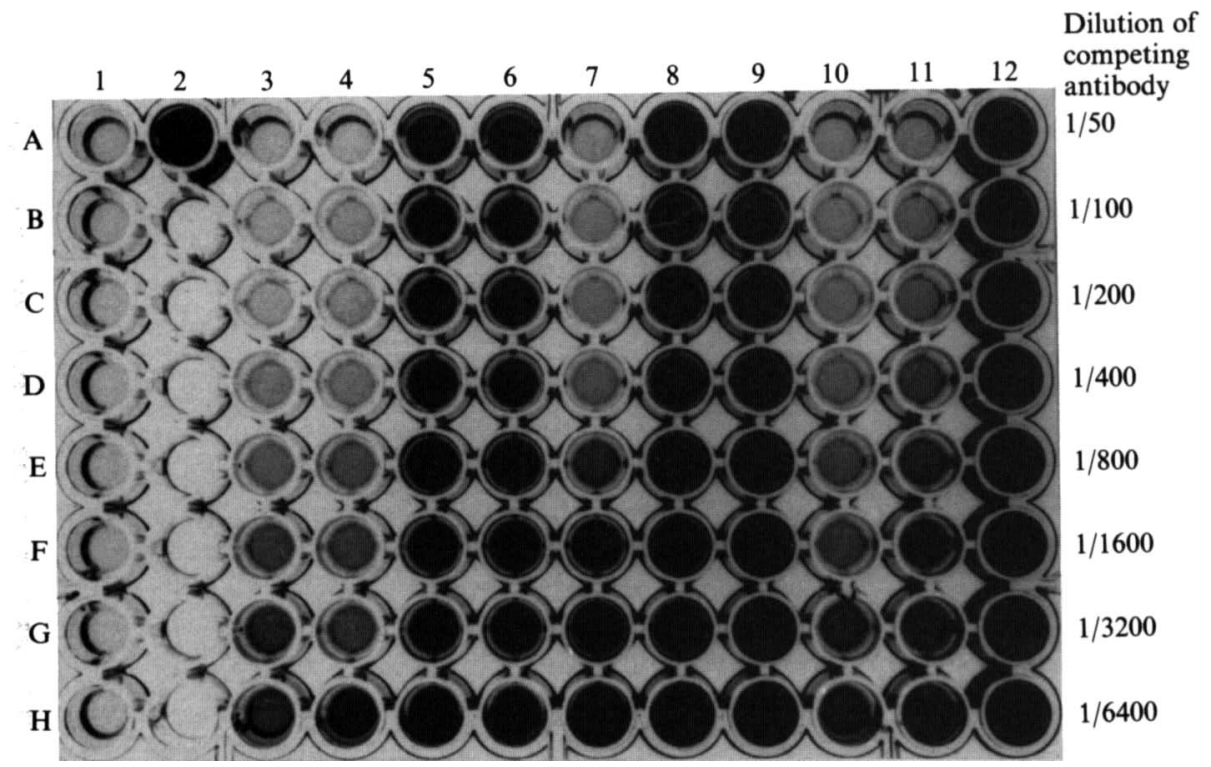

Fig. 4. Urease competition assay using the enzyme catch test. Lane 1, blank (no antigen added); well $2 A$, positive control (no competing antibody added); lanes 3-12, competition respectively with UU8/1 and UU8/11-UU8/19 [twofold dilutions from $1 / 50(\mathrm{~A})$ to $1 / 6400(\mathrm{H})$ ].

eighteen antibodies were also shown to cross-react with active urease from all of the other human serotypes by the enzyme catch test (cf. Precious et al., 1987).

Competition assays with the enzyme catch test demonstrated four distinct epitopes. A typical result with this test is shown in Fig. 4. The wells were coated with UU8/1 and competition assays were carried out against UU8/1 (lane 3) and UU8/11-UU8/19 (lanes 4-12). Competition is evident in lanes 3 (UU8/1), 4 (UU8/11), 7 (UU8/14), 10 (UU8/17) and 11 (UU8/18), suggesting that these monoclonal antibodies all recognize the same epitope. The assays were repeated three times, in each case initially coating the wells with a monoclonal antibody which had shown no competition in previous assays. To confirm these results, an example of a monoclonal antibody which recognized each distinct epitope was radiolabelled and the second competition assay method (see Methods) was followed. The results obtained were in agreement with those from the enzyme catch test. The groupings of antibodies recognizing the four distinct epitopes were: (i) UU8/1, UU8/11, UU8/14, UU8/17-18, UU8/20-23, (ii) UU8/12-13, (iii) UU8/24-28 and (iv) UU8/15-16, UU8/19.

Immunoblots of the fully denatured urease, probed with homologous polyclonal serum and with all of the monoclonal antibodies, confirmed that the $72 \mathrm{kDa}$ subunit was recognized in all instances, and no evidence of antigenicity was detected for either of the two smaller molecular mass subunits. Fig. 2(a) shows an immunoblot (lanes A, C, E, G, I) against the homologous polyclonal serum and against four monoclonal antibodies with different epitope specificities.

\section{DISCUSSION}

The use of a monoclonal antibody affinity column allowed efficient and consistent purification of active ureaplasma urease.

Various molecular masses have been reported for the urease from $U$. urealyticum. Eng et al. (1986), working with six strains, reported a molecular mass of $380 \mathrm{kDa}$ from native gel electrophoresis, but of $179 \mathrm{kDa}$ after treatment with $\beta$-mercaptoethanol and SDS. Precious $e$ t al. (1987) reported two active protein bands of approximately $130 \mathrm{kDa}$ and $180 \mathrm{kDa}$, and Kenny (1983) reported one band of $140 \mathrm{kDa}$. The gel filtration data presented here suggest that the 
purified active enzyme has an apparent molecular mass of $190 \mathrm{kDa}$, whereas the apparent molecular mass on non-denaturing electrophoresis varied from $170 \mathrm{kDa}$ to $220 \mathrm{kDa}$.

Radiolabelling with ${ }^{63} \mathrm{Ni}$ confirmed the presence of nickel in the enzyme - a finding consistent with other ureases such as jack bean (Dixon et al., 1975), soybean, Klebsiella aerogenes, Brevibacter ammoniagenes and Bacillus pasteurii (Todd \& Hausinger, 1987). The activity was unaffected by the presence of EDTA (data not shown), suggesting that the nickel was tightly coordinated in the enzyme. Of the two active protein bands seen after SDS-PAGE, that of higher apparent mass was always more active. The band of apparently lower mass may represent a different conformational state, but the possibility cannot be excluded that aggregates lacking one or more small subunit polypeptides retain some enzyme activity.

Complete denaturation of the enzyme by boiling and SDS-PAGE revealed three subunits, one of $72 \mathrm{kDa}$ containing nickel and others of 14 and $11 \mathrm{kDa}$. These three subunits are similar in mass to the $72 \mathrm{kDa}, 11 \mathrm{kDa}$ and $9 \mathrm{kPa}$ subunits reported for the nickel-containing urease from Klebsiella aerogenes (Todd \& Hausinger, 1987). On the basis of densitometry and assuming that all three subunits stain with Coomassie stain to the same relative sensitivity, we suggest a hexamer of $a_{2} b_{2} c_{2}$ for the ureaplasma urease whereas Todd \& Hausinger (1987) suggested an $a_{2} b_{4} c_{4}$ complex for Klebsiella urease using the same technique. It is noteworthy that jack bean urease seems to exist as a hexamer, although of identical subunits. Previous electrophoretic studies on the composition of ureaplasma urease (Precious et al., 1987; Kenny, 1983; Stemke et al., 1987) have indicated polypeptides of molecular masses from 64 to $76 \mathrm{kDa}$, this being the first to demonstrate the presence of the smaller subunits.

Stemke et al. (1987) reported that their urease preparation retained full activity for at least $20 \mathrm{~d}$ at $4{ }^{\circ} \mathrm{C}$ in phosphate buffer, $\mathrm{pH} 7 \cdot 2$, with $1 \% \mathrm{BSA}$, but our affinity-column-purified enzyme was much less stable. Storage of the purified enzyme at $-70{ }^{\circ} \mathrm{C}$ resulted, on thawing to $20^{\circ} \mathrm{C}$, in a partial breakdown to the three subunits and a loss of $50-55 \%$ of the original activity.

The $\mathrm{pH}$ optimum for the enzyme was shown to be $\mathrm{pH}$ 6.9. This value is higher than that reported by Swanberg et al. (1978), but lower than those reported by Masover et al. (1977 b) or by Eng et al. (1986). The pH of the buffers fell after addition of substrate and PBS and before addition of enzyme, and this may account for the slightly lower value reported here. Although the enzyme was inactivated at $\mathrm{pH} \mathbf{1 0} \cdot \mathbf{0}$, this was reversible since on elution from the affinity column at this $\mathrm{pH}$, followed by dialysis to neutrality, an active preparation was obtained. Dialysis from pH 4.0 to neutrality, however, did not reconstitute active enzyme.

Kenny (1983) showed that inhibition of urease activity inhibited the growth of $U$. urealyticum and Romano et al. (1986) have reported that ATP production by the cells requires the concomitant activity of both the urease and a membrane-bound ATPase. These observations and those of others suggest that this organism may have a novel energy-generating system dependent upon the activity of the urease.

Analysis by isoelectric focusing indicated that the enzyme preparation contained two major protein bands with pI values of 4.60 and 4.68 , the latter apparently being due to the $72 \mathrm{kDa}$ subunit since this was the major component seen on isoelectric focusing of the denatured enzyme. The other band at pI 4.73 in the enzyme preparation is presumably related to the other active component of the enzyme. These $\mathrm{pI}$ values are lower than those quoted by Eng et al. (1986) for enzyme purified chromatographically.

All nineteen anti-urease monoclonal antibodies bound to the active enzyme and to the inactive $72 \mathrm{kDa}$ subunit but to neither of the two smaller subunits, suggesting that the latter were not particularly antigenic, perhaps because they are complexed internally. Competition assays by two techniques revealed four distinct epitopes, all apparently not involving the active site since binding of antibody did not inhibit enzyme activity. It has also been established (data not shown) that the enzyme is not inhibited by homologous polyclonal serum at a 1/100 dilution, a dilution which inhibits the growth of the ureaplasma (Precious et al., 1987). The unavailability of the active site to antibodies suggests that it is in a cleft or pocket. It is interesting that all the monoclonal antibodies to urease of serotype 8 ureaplasma cross-reacted with the native urease from all of the other human serotypes, implying that this important enzyme is conserved across the fourteen human serotypes. 
This work was supported by grants from the Scottish Home and Health Department and from the British Technology Group. We are indebted to Mr I. Armitt for technical assistance.

\section{REFERENCES}

Axen, R., Porath, J. \& Ernback, S. (1967). Chemical coupling of peptides and proteins by means of cyanogen halides. Nature, London 214, 1302-1304.

Dixon, N. E., Gazzola, C., Blakeley, R. L. \& ZERNER, B. (1975). Jack bean urease (EC 3.5.1.5). A metalloenzyme. A simple biological role for nickel? Journal of the American Chemical Society 97 , 4131-4133.

Dulbecco, R. \& Vogt, M. (1954). Plaque formation and isolation of pure lines with poliomyelitis virus. Journal of Experimental Medicine 99, 167.

EnG, H., Robertson, J. A. \& Stemke, G. W. (1986). Properties of urease from Ureaplasma urealyticum: kinetics, molecular weight and demonstration of multiple enzyme isoelectric point forms. Canadian Journal of Microbiology 32, 487-493.

FAHEY, J. L. \& TERRY, E. W. (1978). Ion exchange chromatography and gel filtration. In Immunochemistry, vol. 1, pp. 8.1-8.16. Edited by D. M. Weir. Oxford: Blackwell Scientific Publications.

FISHBEIN, W. N. (1969). A sensitive and non-inhibitory catalytic gel stain for urease. In 5th International Symposium on Chromatography and Electrophoresis, pp. 238-242. Ann Arbor, Michigan: Ann Arbor Scientific.

GeIGY, J. R. (1970). In Documenta Geigy, Scientific Tables, p. 280 . Edited by K. Diem \& C. Lentner. Basle: J. R. Geigy.

Goswami, K. K. A. \& Russell, W. C. (1983). Monoclonal antibodies against human paramyxovirus type 3 and against SV5 virus: preparation and preliminary characterization. Journal of General Virology 64, 1163-1172.

HUNTER, W. M. (1978). Radioimmunoassay. In Immunochemistry, vol. 1, pp. 14.1-14.40. Edited by D. M. Weir. Oxford: Blackwell Scientific Publications.

KENNY, G. E. (1983). Inhibition of growth of Ureaplasma urealyticum by a new urease inhibitor, fluorofamide. Yale Journal of Biology and Medicine 56, 717-722.

KenNy, G. E. \& CARTWRight, F. D. (1977). Effect of urea concentration on growth of Ureaplasma urealyti- cum (T-strain mycoplasma). Journal of Bacteriology 132, 144-150.

Masover, G. K., Razin, S. \& Hayflick, L. (1977a). Localisation of enzymes in Ureaplasma urealyticum (T-strain mycoplasma). Journal of Bacteriology 130, 297-302.

Masover, G. K., Razin, S. \& Hayflick, L. (1977b). Effects of carbon dioxide, urea and ammonia on growth of Ureaplasma urealyticum (T-strain mycoplasma). Journal of Bacteriology 130, 292-296.

Pollack, J. D. (1986). Metabolic distinctiveness of ureaplasmas. Pediatric Infectious Disease 5, S305S307.

Precious, B. L., Thirkell, D. \& Russell, W. C. (1987). Preliminary characterization of the urease and a $96 \mathrm{kDa}$ surface-expressed polypeptide of Ureaplasma urealyticum. Journal of General Microbiology 133, 2659-2670.

RaNDall, R. E., Young, D. F., Goswami, K. K. A. \& Russell, W. C. (1987). Isolation and characterisation of monoclonal antibodies to Simian virus 5 and their use in revealing antigenic differences between human, canine and simian isolates. Journal of General Virology 68, 2769-2780.

Romano, N., La licata, R. \& Alesi, D. R. (1986). Energy production in Ureaplasma urealyticum. Pediatric Infectious Disease 5, S308-S312.

Russell, W. C. \& BlaIR, G. E. (1977). Polypeptide phosphorylation in adenovirus-infected cells. Journal of General Virology 34, 19-35.

Stemke, G. W., Robertson, J. A. \& Nhan, M. (1987). Purification of urease from Ureaplasma urealyticum. Canadian Journal of Microbiology 33, 857-862.

Swanberg, S. L., Masover, G. K. \& Hayflick, L. (1978). Some characteristics of Ureaplasma urealyticum. Urease activity in a simple buffer: effect of metal ions and sulphydryl inhibitors. Journal of General Microbiology 108, 221-225.

Todd, M. J. \& Hausinger, R. P. (1987). Purification and characterisation of the nickel-containing multicomponent urease from Klebsiella aerogenes. Journal of Biological Chemistry 262, 5963-5967. 